\title{
Theorising international monetary relations: three questions about the significance of materiality*
}

\section{Anna Leander**}

\section{Introduction}

Academics spend a lot of time in the company of electronic gadgets. We read and write on them. We use them to trawl the web. We no longer carry around heavy books and papers but computers, tablets, cell phones and cables. Our ways of working and thinking have been transformed. Therefore, it is hardly surprising that social scientists are paying increasing attention to the ways in which the growing reliance on computers as well as rapid changes in information and communication technologies are transforming society. Sociality, subjectivity, law, military operations, intelligence services, diplomacy, marketing and memory, just about everything, have been investigated with a view to understanding and

\footnotetext{
* Received on April $2^{\text {nd }} 2015$ and approved for publication on May $13^{\text {th }} 2015$.

** Professor (MSO) at the department of Management Politics and Philosophy of the Copenhagen Business School, Copenhagen, Denmark; and Professor at IRI PUC-Rio, Rio de Janeiro, Rio de Janeiro, Brazil. Email: ale.mpp@cbs.dk.
}

CONTEXTO INTERNACIONAL Rio de Janeiro, vol. 37, n 3, september/december 2015, p. 945-973. 


\section{Anna Leander}

explaining the significance of technological transformations (Hayles 2012; Mayer-Schönberger and Cukier 2013; Carr 2014).

This interest in technology is paralleled by a renewed and rapidly growing interest in materiality; in objects, and how they become part of social life. Theoretically, this is expressed in a rapidly growing interest in 'new materialisms' (Coole and Frost 2010; Connolly 2013); feminist research on embodiment and materiality (Haraway 1997; Barad 2007), interest in post-humanist philosophies (DeLanda 2006; Amoore 2013); and the social studies of science and technologies, including perspectives offered by Actor Network Theory (Latour 2005; Law 1991). This interest has also found expression in international relations (IR) and international political economy (IPE). International Political Sociology has published a forum on this subject (Best and Walters 2013), and Millennium has devoted a theme issue to the topic (Srnicek et al 2013).

In my contribution to this special issue of Contexto devoted to Benjamin Cohen's work, I reflect on the implications of these developments for how we theorise the politics of international monetary relations. I build on a rapidly expanding body of work in the social studies of finance (SSF), including those of Knorr-Cetina and Preda (2005) and MacKenzie (2006). These and other scholars have developed an interesting range of insights into the significance of materiality in social processes, but they have less to say about international power and the hierarchies of power that have preoccupied IPE scholars, including Cohen. Therefore, even IPE insiders, working in the broadly defined SSF tradition, argue that SSF insights are best used in combination with other approaches that have more to say about politics (see Porter 2013). This article explores what such 'combinations' might look like. This could easily become a massive undertaking, with many different dimensions. However, I will restrict it to three basic questions: about the ontology, agency, and scope of international monetary relations. 
Theorising international monetary relations: three questions about the significance...

Raising these questions in relation to Cohen's work highlights their significance for IPE theorisations more generally. Cohen is an established authority on the politics of international monetary relations as well as IPE in general (see Guzzini in this issue). Moreover, some 15 years ago, Cohen published an article on the significance of 'electronic money', defined as money 'based on encrypted strings of digits - information coded into series of zeros and ones - that can be transmitted and processed electronically' (2001:200). In this article, reprinted in his book The future of money (2006), Cohen explored the political significance of digital money with the aim to '... move beyond preliminary prognostications to attempt a more systematic exploration of electronic money's prospective challenge to the traditional authority of Central Banks'(Cohen 2001:199). Therefore, although other scholars have obviously begun to think about the implications of SSF insights for the politics of international monetary relations (Langely 2008; De Goede 2006, 2013; McKeen-Edwards and Porter 2013; Best 2007), relating these questions to Cohen's 2001 article has a double advantage. It engages one of the most established and influential scholars in this field, and one who argues in terms cognate to IPE scholars across the world.

This article follows Cohen's suggestion that we practice IPE as a 'global dialogue'. It does so by raising three questions from elsewhere. However, this 'elsewhere' is not the geographical 'elsewhere' Cohen writes about in his textbooks. It is a theoretical 'elsewhere' where Cohen's questions about politics, articulated as questions about the hierarchy of currencies or the authority of central banks, play no significant role, and no strong views are held on the answers. Therefore, engaging with Cohen's work from this place is not primarily about whether his answers are right or wrong, but rather about his questions. As shown below, the questions one asks obviously shape the answers one gives. However, the main emphasis 


\section{Anna Leander}

here is on the questions; why taking the materiality of electronic money seriously leads to reconceptualising its ontology, the political agency tied to it, and the scope of its politics; and why doing so is politically important.

\section{Ontology: are contemporary currencies hybrids of electronic money?}

The first and most obvious question is whether the material side of 'electronic' has been adequately integrated into Cohen's analysis. Indeed, one of the core, if not the core, ambition of much of the theorising in the SSF tradition is to draw attention to the ways in which the material is part and parcel of politics, and integrated into governance technologies, devices, assemblages, boundary objects, or topologies. In what has become known as an 'ontological turn', scholars are widely debating the status of the material (see, for example, Latour and Weibel 2005). One way of pursuing this question in a discussion about the political dimensions of international monetary relations is to focus on whether or not the ontology of money requires rethinking in what Cohen terms 'the age of electronic money'. If it does, this raises further questions about the adequacy of conceptualising the politics of international monetary relations in terms of currency competition and central bank authority alone.

In his 2001 article about electronic money, Cohen (implicitly) dismisses the need for a reconceptualisation of money and currencies as 'hybrids', with the material mixed with the social. Through a definitional move, Cohen excludes the need to examine the significance of electronic money for the ontological status of currencies, including conventional ones. He defines electronic money in a way that sets it up as a specific kind of digitised money; a 
Theorising international monetary relations: three questions about the significance...

currency that is electronic in form. ${ }^{2}$ This restricts questions about the ontological implications of the move to the digital in general to this specific new form of money. It also allows him to frame the question of its implications for the politics of international monetary relations in the same terms as in his earlier work: he sets up his argument as one where emerging electronic currencies are 'competing', as he puts it, with conventional state-owned currencies. He explicitly argues that this innovation and the competition it engenders echoes analogous developments in the past. For him, the interesting question is therefore how the extension ${ }^{3}$ of currency competition to include electronic money will affect the hierarchies among currencies, and how this will refashion the capacity of central banks to manipulate their currencies and use them for political purposes. The political question for Cohen is what happens to the hierarchies among conventional currencies and the political leverage of central banks when competition among currencies is extended in this way.

Cohen's conclusion on both accounts is unexpected, and therefore also thought-provoking. In matters of monetary management, Matthew's Law (as formulated by Billie Holiday) that 'the strong get more while the weak ones fade' almost invariably applies. Not so, Cohen reasons, when it comes to electronic money. On the contrary, in countries with weak currencies, the new competition will just worsen the already weak authority of central banks; it will essentially be a case of more of the same. For countries with strong currencies, it will bring about a more significant qualitative change; an erosion in the value of their currencies, and fewer options to manage those currencies and maintain their value. In Cohen's words:

In the many economies around the world where central bankers are already experiencing increased difficulty in controlling monetary aggregates, owing to accelerating cross-border competition among currencies, the main impact of electronic money will be simply to 


\section{Anna Leander}

add to the intensity of that competition. By contrast, in the traditional reserve centres - the US, 'Euroland' (home of the new euro), and Japan - the threat to state power appears distinctly greater, and will demand real adjustments by policy-makers (Cohen 2001: 199).

Cohen advances this argument by distinguishing between the control and autonomy of central banks, with 'control' referring to central banks' capacity to control the monetary supply, and 'autonomy' to their capacity to manage demand for their currencies. ${ }^{4}$ In Cohen's view, all central banks have lost 'control'; hence the emergence of electronic money changes little. The difference arises on the autonomy side where the 'strong' currencies that are high up in the currency hierarchy have something to lose. Cohen suggests that the emergence of electronic money may eventually make those currencies less attractive, thereby forcing the central banks managing them to court the markets. As a result, they will end up in positions similar to those of their less fortunate counterparts who are already managing weaker currencies further down the hierarchy. ${ }^{5}$ There will be a levelling towards the bottom, as those states with some authority lose it; a reversal of Matthew's Law, as it were. This is a rare thing in the politics of international monetary relations.

Cohen's analysis has the advantage of directing attention to the political significance of electronic money (as one would expect from any IPE analysis). However, viewed through SSF glasses, the way in which this is done seems unfortunate. This is not because the political dimension is presented in terms of central bank authority and currency competition, which would be a classical objection in IPE. What about the implications for political control by states and for democratic accountability (Strange 1999; Underhill 1995)? Rather, the core concern would be that by postulating a neat separation between electronic money and conventional currencies, Cohen 
Theorising international monetary relations: three questions about the significance...

dispenses with the need to address the implications of the electronic age for the ontology of conventional currencies. Can we really continue to assume that currencies are what they always were, and that electronic money is just another currency?

While Cohen is clearly justified in stressing that euros, dollars and rands differ from bitcoins, and that bitcoins may affect currency competition and the role of central banks, SSF scholars would try to move the discussion. Instead of assuming that currency remains a stable category despite the advent of electronic money, they would be interested in probing the notion of 'hybridity'. They would want to explore ways in which the social and the material are intertwined in the very conception of 'currency' - and, on the flip side of the same coin, seek to underline the nefarious consequences of assuming that the material and the social can be neatly separated.

The thrust of their enquiry would be to highlight ways in which the 'material' should be integrated, on par with 'social', into the ontology of money. This is not to say that the material should be regarded as a deus exmachina; merely that it has to be explicitly recognised in the relations, processes, mechanisms and politics studied by social scientists which would otherwise be misunderstood (see, for example, Knorr-Cetina 1997; Callon 2008; andLatour 2005).

Bringing this perspective to bear on Cohen's discussion of the significance of electronic money, the first and obvious question would be whether electronic money should not be classified and analysed as a 'hybrid' of conventional money. An argument pitting electronic currencies against conventional ones would seem suspicious, reflecting an unjustified separation of the material and the social, thereby preventing the most important questions and insights about its significance from emerging. What if the core question about electronic currencies indeed arises from the way in 


\section{Anna Leander}

which conventional currencies have become socio-material 'hybrids'? Or, in more banal and basic terms, what if electronic money is important not because it competes with the dollar, euro or peso, but because it transforms those conventional currencies from within by making them electronic? What if the significance of electronic currency lies less with Mondex, Visa Cash, DigiCash /eCash, CyberCoin, NetCash or bitcoins and more with the way in which conventional currencies such as the dollar, rand, real or euro are themselves becoming electronic? If currencies are changing in this way, what are the implications for the competition among currencies, and the capacity of central banks to influence this competition and turn it to their advantage? Would Matthew's Law still have been partially reversed?

These are important questions that all derive from interrogating the ontological status of electronic money. Therefore, my first question to Cohen would be: What is the ontological status of electronic money? Does a definition of electronic money that excludes the hybridisation of conventional currencies omit what matters most about the politics of international monetary relations? I would also like to know whether Cohen thinks such a definition is still tenable. Have most currencies not also become electronic? Is the relationship between conventional and electronic money really an either/or, rather than a both/and? Are most monies in the contemporary world, including electronic money, not 'hybrids'? Arguably, electronic money is no longer our future; it has become our present. The electronic is omnipresent in all our currencies. Given this, we need to ask how that hybridity, and the electronification on which it rests, are reshaping the politics of international monetary relations. I do so below by further engaging with the politics of international monetary relations in the age of electronic money. I examine two aspects, namely political agency in international monetary relations, and the scope of the politics involved in it. 


\section{Theorising international monetary relations: three questions about the significance... \\ Agency: is political agency displaced by and to material actants?}

As noted earlier, Cohen theorises about the political significance of electronic money by asking how it affects the authority and control of central banks. He argues that the 'threat' to this authority is differentiated; central banks in countries with stronger currencies stand to lose more because they still have some authority, whereas those in countries with weaker currencies have already lost a lot of control as well as authority, so stand to lose less. His argument rests mainly on the way in which competition from electronic money affects the trust placed in central banks by people active in monetary markets. While the argument seems persuasive, the SSF scholar would ask whether it sufficiently acknowledges the role of the material in bringing about these shifts. My second question would therefore be whether political agency is also material. Could material processes also be central to the displacement of the authority of central banks, and could some of that authority move to these processes rather than to other market actors?

En route to his general conclusion (the reversal of Matthew's Law), Cohen assesses how electronic money is eroding authority. He rejects arguments (among others by Helleiner, another contributor to this issue) to the effect that the threat posed by electronic money is vastly overstated (2001: 218-221). By contrast, he argues that electronic money will erode trust in conventional currencies, and even more so in the ability of central banks to exert their authority over those currencies. This would constitute a significant erosion of authority, implying that it is no longer uncontested. ${ }^{6}$ Cohen insists that the increased rivalry among currencies will undermine current trust in conventional currencies backed and guaranteed by central banks. This overarching process, Cohen argues, is bound to be reinforced by a number of practical developments tied to electronic 


\section{Anna Leander}

money that further erode the standing and authority of central banks. In particular, he insists that market actors have already developed clearing mechanisms that operate independently of central banks. This, he avers, is a concrete way of eroding trust in the authority of central banks over money markets. He also argues against the notion that because money transactions cannot take place in outer space, there will always be a jurisdiction in which central banks can exert their authority. Instead, he believes there will be plenty of scope for playing on the multiplicity of jurisdictions, and engaging in 'jurisdiction-hopping or shifting'. Echoing Susan Strange's view that the state is not disappearing but 'hollowing out', as politics is simply moving elsewhere in a massive 'sea change' (Strange 1996 and 1990 respectively), Cohen notes:

The risk is not that the power of the sovereign state will disappear-at least not in the sense of the state's ability to control the supply of its own money. Rather, it is that as the population of the monies grows [...] the power of the state will simply become more and more irrelevant. The autonomy of monetary policy will, gradually, just fade away (Cohen 2001: 220).

In this argument, there is little scope for thinking about the role of material processes themselves. It focuses on how central banks and other market actors are reacting to the emergence of a new type of currency.

Cohen acknowledges the significance of the material process for the emergence of electronic money. He sees this as a precondition of sorts for the very fact that electronic currencies can exist and be competitive. In an early insight into what has since become a core preoccupation of IPE and IR more generally, Cohen engages the importance of infrastructures, notably, in his terms, 'infra-structure' and 'info-structure'. He makes the point that their implications for 
Theorising international monetary relations: three questions about the significance...

the prospects of electronic money rivalling conventional currencies are diverse, and writes:

In network theory, two distinct structures are recognised in the configuration of spatial relations: the 'infrastructure', which is the functional basis of a network; and the 'infostructure', which provides needed management and control services. Economies of scale, by reducing transactions costs, obviously promote a consolidation of networks at the level of infrastructure [...] But at the infostructure level, the optimal configuration tends to be rather more decentralised and competitive, in order to maximise agent responsibility (Cohen 2001: 205).

According to Cohen, the resulting trade-off between transactional efficiency (determined by the infrastructure) that would tend to produce concentrations on the one hand, and outright monopolies and currency stability (shaped by the infostructure) on the other, is likely to lead to a situation in which 'once electronic money gains widespread acceptance, a smallish population of currencies is far more likely than a single universal money' (Cohen 2001: 206). This shows that Cohen is well aware of the importance of material processes, but confines them to a background condition of sorts that has no active and direct role in fostering competition.

From an SSF perspective, the emphasis on infra-/info-structures is significant (see Fuller and Goffey 2012). However, excluding the potentially active role of the material in fostering competition between electronic and conventional currencies, thus weakening central bank control over the latter, seems less fortunate. The core concern would be that it precludes the material from having a 'performative' quality, that is an agential quality. By contrast, SSF theorists would argue that it is important to press questions about 


\section{Anna Leander}

how material 'actants" ${ }^{7}$ form part of the politics which fashion the authority of central banks, as opposed to the structural conditions which fashion the activities of market actors. As Callon (2008) has put it, it would be important to break with a 'prosthetic' understanding of the role of the material in agency, and replace it with an understanding of how material 'habilitates' agency. Where a prosthetic understanding focuses on how the material augments the possibility for agency so that it approximates a normal or ideal form(as the prosthesis does for the otherwise handicapped), a habilitated understanding assumes that the material is always already integral to the agency, as it is part of the 'agencement' through which agency functions. The material is an inescapable part of agency.

Switching from a prosthetic to a habilitated understanding of the how the material is tied to agency is important not least for political reasons. With such a move, Callon argues, politics ceases to revolve around the slogan:

Adjust, with the help of prostheses, to finally be self-entrepreneurial individual agents ... Instead, let us produce socio-technical agencements that are flexible, adjustable and robust, and allow different individuals to fit into the interactive rationale characterizing neo-liberal individual agency, irrespective of where they are and the period of their lives (Callon 2008: 46).

This raises the question of whether adopting a perspective allowing for material agency in theorising about the significance of electronic money might yield some interesting perspectives on Cohen's arguments. The extensive SSF literature (and that one could see as part of a broadly defined IPE) ${ }^{8}$ suggests that this may be the case, in at least two ways.

First, it would bring out the role of the material in defining who can act (and is acting) in the currency markets, on what terms, and how 
Theorising international monetary relations: three questions about the significance...

they influence currency competition and the regulatory roles of central banks. For example, Donald MacKenzie's ethnographic research suggests that foreign exchange markets arereshaped by high frequency trading (HFT) (MacKenzie 2014a). However, HFT in foreign exchange markets is more difficult than in other financial markets. This is due partly to the imposition of technical standards that make HFT trading less effective. The market has a slower internet protocol (called FIX) than that adopted in other markets, adopted mainly because it was compatible with the technological systems already in place. Similarly, HFT in foreign exchange markets is also slowed by a practice called 'the last look', through which the legality and legitimacy of proposed trades are checked, accepted or vetoed. This check is done in a very short time period ranging from five milliseconds to a couple of seconds. Obviously, this is not long enough for humans to assimilate a proposed transaction, let alone form an opinion about it. It is therefore perhaps more accurate to say that the algorithms (sic) have 'the last look' in which they check the legality and legitimacy. In clear, the dual laggardness of HFT in foreign exchange markets does not reflect states' attempts to preserve the privileges of seigniorage or control their currencies. The banks imposing these rules are not central banks, but large private ones. ${ }^{9}$ More than this, the laggardness has been induced by technological systems and the control is exercised by algorithms. This argument vindicates Cohen's contention that the threat 'electronic money' poses to the politics of money is indeed real. However, it also underlines that an understanding of materially habilitated agency is essential to get a grasp of how that threat works. The material (the FIX protocol and the algorithms doing 'the last look') is part of the 'agencement' displacing the central banks.

Second, and relatedly, SFF theorists have suggested that the material matters not only because of its role in displacing central banks, but also because political agency is increasingly located inside material 


\section{Anna Leander}

processes, such as those featuring the algorithms referred to earlier (MacKenzie 2014b).The advent of electronic money has led to a situation in which algorithms are effectively buying and selling currencies, in response to developments in the markets. In January 2007 , more than 80 per cent of yen-euro trade, more than 60 per cent of yen-US dollar trades and more than 50 per cent of euro-US dollar trades involved algorithms ${ }^{10}$ (Chaboud et al 2014: 2052). This means that algorithms are becoming active participants in the (fundamentally political) definition of the value of currencies. They are political actors in their own right. This is well captured by considering the role they have begun to play in the politics of these markets, including the efforts of central banks to regulate them. Central banks no longer attempt to control only the actions of institutional or individual participants in the currency markets, but also the actions of algorithms. It has become necessary to distinguish between acceptable and unacceptable algorithms, and also to think about how to allocate responsibility when those algorithms break market rules. This discussion does not lie in the future. It is a current and ongoing debate, and extends to relatively simple and 'stupid' algorithms. The algorithms in HFT are simpler than those used in other areas. ${ }^{11}$ They do not 'learn', or update or rewrite themselves. They are nonetheless programmed to react to shifting relational constellations. Given that those constellations are varied and complex, the algorithms often act in unforeseen ways, which were not intended in the initial programming. This dovetails with Cohen's concern that political agency is moving away from central banks (and the state). However, it adds a different perspective on where that agency is moving to; it suggests that it is being diffused not only to institutions and people, but also to material actants (algorithms).

Drawing attention to the place of material political agency raises various issues in the politics of international monetary relations that Cohen does not explore. In SSF they are regarded as essential. In fact, 
Theorising international monetary relations: three questions about the significance...

Karin Knorr-Cetina, a prominent scholar in this field, has structured her entire assessment of the changes in the financial order around their changing centrality. In her view, the conventional 'network-based' form of organisation in which objects and humans are intertwined has given way to a 'scopic' mode of organisation in which interaction is mostly human, but is mediated by objects and technologies (the screen, the mouse, and so on) and, more recently, an 'interaction order of algorithms' in which most market interaction is undertaken by non-human agency (Knorr-Cetina 1997 and 2005). This is not necessarily the only way of characterising financial orders, and not everyone interested in the politics of international monetary relations should centre their work exclusively on material agency. However, it would be interesting to hear Cohen reflect on whether or not material political agency deserves a more prominent place.

\section{Scope: is the locus of the politics of international monetary relations expanding?}

Cohen has amply demonstrated his intention to give the political a real place in IPE. He began his career by focusing on questions of imperialism, and has relentlessly reminded his readers that politics matter (see Guzzini in this issue). One of Cohen's main concerns with 'American' IPE is that it marginalises politics in its quest for ever-increasing scientific rigour (Cohen 2007). From an SSF perspective, though, an obvious question would be: which politics? Indeed, one of the most charming aspects of SSF and the new materialism is that it makes a point of not predefining what politics is about. Instead, SSF scholars trace the associations that make up politics, departing from the assumption that these will change in time and, with them, the locus of politics. This explains the emphasis on 


\section{Anna Leander}

new 'roles' or 'positions' (Power 2005); ways in which 'boundary objects' (Star 2010) can tie together contexts and generate novel forms of collaboration among various actors; or the reflexive implications of theoretical knowledge/expertise that could itself become an 'engine and not a camera' (Mackenzie 2006) in the course of defining politics. Therefore, my third and final question to Cohen is whether one should not consider how the evolving materiality of money is redefining the locus and scope of politics.

Cohen devotes considerable attention to politics, but not its evolving boundaries. In his analysis of electronic money, he explicitly addresses the conventional IPE question cui bono? which Susan Strange (1998) thought every scholar should ask in his or her own way. Cohen's way of asking it is to explore how electronic money could change 'the geography of money: the broad configuration of global currency space' (Cohen 2001: 205). For him, this includes questions about which currency is a top currency and which currencies are weaker. It also includes the related issue of how much scope central banks are likely to retain for influencing the relationships among these currencies. I appreciate Cohen's intention to illuminate the linkage between hierarchies and politics, and the way in which this differentiates IPE from other research traditions. However, Cohen focuses on questions of hierarchy in a specific field, namely the 'global currency space'. This ignores the core SSF concern about not predefining the locus of politics. The politics here is about currencies; the field has neatly settled boundaries. But what if electronic money mattered not only for the hierarchies among currencies and the authority of the central banks managing those currencies, but also for the scope of monetary politics? Could electronic money be folding monetary issues into other areas; expanding the politics of international monetary relations beyond hierarchies among currencies? Indeed, would this not begin to suggest that the hierarchy among currencies and the authority of 
Theorising international monetary relations: three questions about the significance...

central banks may also be defined by relationships that have little to do with money supply, the monetary aggregates M0-M4, discount rate policies, or open market operations? An SSF perspective would not exclude such a possibility, but encourage its investigation. While not denying the significance of Cohen's questions about politics in the global currency space - in other words, questions about hierarchies among currencies and the authority of central banks - I wonder whether examining the ways in which electronic money are refashioning the locus of politics would also not be important, especially since it is bound to have consequences for the relations among currencies as well as the authority of central banks.

Again, insights from SSF seem to confirm that this would be a fruitful enquiry. Linkages between money (and finance) and security have attracted increasing attention not only in SSF but in IR in general. In politics, it is captured by the adage 'follow the money', and in academia, by the growing number of projects that link finance and security (Leander et al 2011; Best and Gheicu 2014). The importance of 'electronic' money for these developments cannot be overstated. It was clear from early on that the digital and cyber age would not only improve the speed and efficiency of financial transactions, including foreign exchange transactions, but would also create new possibilities. The traces left by digital transactions as well as the electronic infra-/info-structures through which they take place make it possible to observe and record behaviour. This possibility has of course been drawn upon extensively by companies (and others) wishing to understand consumption patterns. But it has also been extensively used for security and military-related surveillance (Baumanetal 2014). Indeed, data mining and profiling have come to epitomize the intertwining of security and monetary politics brought about by the advent of electronic money (Gutwirth and Hildebrandt 2008). This has far-reaching implications for the way in which we think about the politics of international monetary relations, as illustrated by two examples. 


\section{Anna Leander}

First, the intertwining of finance and security is wreaking havoc with the assumptions that underpin conventional analyses of the politics of international monetary relations. It is changing who the central actors are, what kinds of interests they pursue, and what kinds of strategies they rely on. Indeed, it can no longer be assumed that 'the goal of monetary policy ... is to keep aggregate spending in line with production capacity', and that central banks therefore intervene through instruments designed primarily to shape "the overall stock of money circulation' (Cohen 2001: 211). Rather, central banks are bound to have other goals, including security-related ones, and their interests, instruments and strategies for intervening in currency markets will also reflect these. This is also true of private banks and other market actors. They are entangled in multiple institutional arrangements in which, among other things, they interact directly with police agencies and intelligence services. As a result, they have developed a new range of interests and instruments reflected in their market interventions, including those captured in the FATF Black List, the Politically Exposed Persons List, and the UN list of suspected terrorist organisations and individuals (see DeGoede et al 2015).

But the changes go deeper than this. Interests and strategies are not only transformed through outside collaboration; they are also transformed from within. As banks and financial institutions have become 'policemen', they have increasingly hired intelligence and security professionals, and financial staff occupy a growing place among security professionals (Nitsche and Hope 1993). This intertwining of professions within organisations is often conflictual and counterproductive. ${ }^{12}$ However, it collapses any general and straightforward assumption about political strategy, and underscores that those strategies cry out for analysis; their locus and scope cannot be assumed ex ante. Therefore, the first question SSF scholars should ask Cohen is whether the politics of international monetary relations 
Theorising international monetary relations: three questions about the significance...

should not be theorised in ways that account for this (potential) shift in locus.

Second, public debate is increasingly folding the politics of monetary management into other issues. The (still unravelling) SWIFT affair is a case in point. ${ }^{13}$ The 'affair' was produced as the European Parliament (EP) tried to limit the collaboration between the SWIFT financial communications system and the United States intelligence services. The EP thought it could affirm Europe's 'normative power' by insisting that civil rights be prioritised over security considerations. It therefore contested the way in which an arrangement originally made to facilitate financial/monetary transactions had become an intelligence arrangement. In effect, it argued that controls over the infra-/info-structures of monetary management also had ramifications for other areas of policy; in this case, the politics of intelligence. In this specific case, it refashioned the trade-off between intelligence and the protection of privacy and basic rights, often referred to as the liberty-security tradeoff, by tilting it sharply towards the intelligence side. ${ }^{14}$ The SWIFT affair demonstrates strikingly that the politics of monetary relations is not restricted to currency hierarchies and the authority of central banks; by contrast, it is about the 'global politics of European security' (De Goede 2012).

Perhaps the politics of international monetary relations was always also about security. Jonathan Kirshner (1995, 2007), for example, has shown that the politics of money is part and parcel of power politics. But be this as it may. What matters here is the conceptual argument about the significance of electronic money in folding the politics of monetary relations and international security/military intelligence into each other. This significance is repeatedly confirmed. Indeed, it is now so well established that PwC could build its 'World in Beta' marketing campaign around it, with slogans such as: 'Where others see an invasion of privacy, we see the world's most 


\section{Anna Leander}

secure transaction'; and 'where others see toy helicopters, we see a mobile task force'. ${ }^{15}$ The campaign won the Chartered Institute of Marketing (CIM) Excellence Award in April 2015. The slogans, campaign and award confirm the extent to which we have become accustomed to the idea that the move to the digital is pushing the boundaries of politics, as well as the arguments of those who are resisting this change. This raises the question of whether the politics of international monetary relations should not be theorised in a way that incorporates this shift in the locus of monetary politics.

In sum, my third question is about the importance of electronic money for the locus and scope of the politics around money. Could it indeed be the case that the advent of electronic money changes not only actors' understandings of their own interests, instruments and possibilities in monetary politics, but also their understanding of what monetary politics are all about? If so, are we not losing something fundamental about the significance of electronic money if we continue to theorise in a way which assumes that the locus and scope of monetary politics is fixed, and that the advent of electronic money changes nothing?

\section{Conclusion}

This article has been prompted by an acknowledgement of Cohen's contribution to the theorisation of the politics of money in IPE, and especially his pioneering work on the political significance of electronic money. It has been written in the spirit of constructively engaging with Cohen's work, rather than criticising it, or challenging the empirical conclusions to which it leads. Cohen's general conclusions about the challenge electronic money poses to the authority of central banks (those who have any authority that can be challenged), appear persuasive. More specifically, I have raised three questions about the theoretical significance of materiality derived from the theoretical 'elsewhere' of the SSF. The first was 
Theorising international monetary relations: three questions about the significance...

about the material ontology of contemporary currencies, asking if we do not need to conceive of electronic money as a hybrid of (rather than a competitor to) conventional money. The second was about material political agency, asking if political agency is not being shifted by and to material agents. The third question was about materially induced change in the scope of monetary politics, asking if materiality should not be conceived of as redefining conceptions of what international monetary relations are about.

I have raised these questions because they open paths of investigation of political import. I have done little more than point to them as I am uncertain where they would lead. However, asking questions and being uncertain about the answers is indeed where acquiring knowledge about something necessarily begins. Acquiring knowledge certainly is a (if not the) core aim of pursuing IPE as a global conversation. So perhaps asking questions is less inferior to advancing claims than it might seem?

To conclude this article, I am tempted to wrap my three questions into one. In his introduction to the discussion of how and when 'electronic money' will pose a serious threat to conventional currencies, Cohen tells us: 'To begin, a number of tricky technical issues will have to be addressed, including inter alia adequate provisions for security (protection against theft or fraud), anonymity (assurance of privacy), and portability (independence of physical location) (2001: 201). My single question would be: are these issues really just technical? Does this formulation not build out the politics of materiality this article has directed attention to by turning it into nothing more than 'tricky technical issue'? If so, does it not relinquish the focus on politics (or at least part of it) that is the distinguishing feature of IPE research, including Cohen's conception of it? To take a cue from another excellent title by Cohen: Do we not need to hang onto the focus on politics if we, as IPE scholars, are to remain 'interesting' and preserve a place for ourselves as more than adages to other specialisms (Cohen 2010)? 


\section{Anna Leander}

And is the politics of materiality not particularly important in a 'world in Beta', as PwC Marketing has put it, where just about everything is digitised?

\section{Notes}

1. I would like to thank my colleague Ann-Christina Lange for updating me on the relevant developments in the social studies of finance, and generously commenting on earlier drafts; Ole Bjerg, Catia Gregoratti, Laura Horn, Renee Ridgeway, Michael Strange, and Diane Tussie, who read and commented on this article; and Jerry Cohen, for his generous response to the first version of this article presented at a panel honouring him at the ISA-FLACSO meeting in Buenos Aires in July 2014.

2. As Cohen explains: 'As electronic commerce(e-commerce) expands, it seems only a matter of time before various innovative forms of money, based on digital data and issued by private market actors, begin to substitute in one way or another for state-sanctioned banknotes and checking accounts as customary means of payment' (2001:198).

3. Thanks to one of the anonymous reviewers for suggesting this helpful formulation.

4. As Cohen states: 'Analytically, we may distinguish between two key questions - what we may refer to as the separate issues of control and autonomy. Control refers to the Central Bank's technical capacity to manage the money supply. Can officials generate increases or decreases in the stock of its own currency at will? Autonomy, by contrast, refers to the Central Bank's policy capacity to manage demand' (2001:212).

5. Cohen notes: 'Despite their loss of exclusive control of money supply, and their local monopolies, states still retain an ability to influence nominal demand insofar as they can successfully compete, inside or across borders, to sustain use of their own currency rather than others. The targets of policy are the users of money, at home or abroad. The aim of policy is to sustain or enhance a national currency's use, almost as if monies were like goods to be sold under registered trademarks [...] Monetary policy, in short, has become something akin to a contest for market loyalty' (2001:214). 


\section{Theorising international monetary relations:}

three questions about the significance...

6. Indeed, a hallmark of authority is that it remains uncontested. Of course, scholars view authority in competing ways (Krieger 1977). Not everyone would agree with Arendt (1958) that authority is consensual. However, traditions that emphasise the contentious nature of authority also emphasise that authority rests on a lack of open contestation (Flathman 1980; Hibou 2011).

7. 'Actants' is a term borrowed from literary theory, where it refers to people or things that make things happen in a plot.

8. In tune with IPE, what I see as the most venerable aspect of the IPE tradition but also with Cohen's instance on dialogue, I think that we should retain an open and inclusive understanding of IPE. As Best and Paterson recently put it 'the very effort to define what IPE 'is' and 'is not' is precisely the kind of reifying move that our volume was trying to avoid. The goal of our project was precisely not to create a new theory, school or approach that could then be put into contention with other such perspectives within something called 'IPE' (Best and Paterson 2015: 739).

9. Provided I understand it correctly, of course. MacKenzie makes no mention of Central Banks in his account. My argument here hinges on the hopefully justified assumption that the banks he discusses are indeed private banks.

10. Fifty-day moving averages of VAT, the percent of total volume with at least one algorithmic counterparty.

11. This argument is derived from Ann Christina Lange's fieldwork. I thank her for discussing it with me.

12. Amicelle (2012), for example, suggests that the involvement of security professionals in the management of money has actually made it more difficult to follow electronic money trails. He also argues that constant misunderstandings and competition between the professional communities (of bankers and intelligence services) severely hampers the exploitation of the potentially enormous possibilities offered by the collaboration around electronic money for both sides (Amicelle2013).

13. SWIFT the (Society for Worldwide Interbank Financial Telecommunication) is the electronic 'postal service' for the financial industry. The worldwide SWIFT network carries 14 million messages a day, or 3.5 billion messages a year. Half of the traffic consists of payment messages.

14. This is misleading, as logical links between intrusive intelligence services and security as well as between liberty and privacy are strenuous and complex to say the least (e.g. Bigo and Tsoukala, 2008). 


\section{Anna Leander}

15. To access these films, see $<$ https://www.youtube.com/watch? $v=$ E7_BiZgkxTI> and <https://www.youtube.com/watch?v=-O6tCGWYCH4> respectively (both accessed on 27 May 2015).

\section{References}

Amicelle, Anthony. 2012. 'Trace my money if you can: European security management of financial flows'. In Ulrika Mörth and Karin Helgesson (eds), Securitization, accountability and risk management: transforming the public security domain. London:Routledge, pp. 110-31.

2013. 'Les professionels de la surveillance financiere:le malentendu comme condition de possibilité'. Criminologie 46 (2): 195-219.

Amoore, Louise. 2013. The politics of possibility: risk and security beyond probability. Durham: Duke University Press.

Aradau, Claudia. 2010. 'Security that matters: critical infrastructure and objects of protection'. Security Dialogue 41(5): 491-514.

Arendt, Hannah. 1958. Between past and future: eight exercises in political thought. London: Faber \&Faber.

Barad, Karen. 2007. Meeting the universe half-way: quantum physics and the entanglement of matter and meaning. Durham and London: Duke University Press.

Bauman, Zygmunt, Didier Bigo, Paulo Esteves, Elspeth Guild, Vivienne Jabri, David Lyonand and RBJ Walker. 2014. 'After Snowden: rethinking the impact of surveillance'. International Political Sociology 8(2): 121-44.

Best, Jacqueline. 2007. The limits of transparency: ambiguity and the history of international finance. Ithaca: Cornell University Press.

Best, Jacqueline and Alexandra Gheicu (eds). 2014. The return of the public in global governance. Cambridge: Cambridge University Press.

Best, Jacqueline and Matthew Paterson. 2015. 'Towards a cultural political economy - not a cultural IPE'. Millennium 43(2): 738-40. 
Theorising international monetary relations: three questions about the significance...

Best, Jacqueline and William Walters. 2013. 'Actor-network theory and international relationality: lost (and found) in translation'. International Political Sociology 7 (3): 332-49.

Bigo, Didier and Anastassia Tsoukala (eds). 2008. Terror, insecurity and liberty: illiberal practices of liberal regimes. New York and London: Routledge.

Callon, Michel. 2008. 'Economic markets and the rise of interactive agencements: from prosthetic agencies to habilitated agencies'. In Trevor Pinch and Richard Swedberg (eds), Living in a material world: economic sociology meets science and technology studies. Boston: Massachusets Institute of Technology, pp. 29-56.

Carr, Nicholas. 2014. The glass cage: where automation is taking us. London: Penguin.

Chaboud, Alain P, Benjamin Chiquoine, Erik Hjalmarssonand Clara Vega. 2014. 'Rise of the machines: algorithmic trading in the foreign exchange market'. The Journal of Finance LXIX(5): 2049-84.

Cohen, Benjamin J. 2014. Advanced introduction to international political economy. Northampton (MA): Edward Elgar.

2010. 'Are IPE journals becoming boring?'. International Studies Quarterly 54(3): 887-91.

2007. 'Comment: The transatlantic divide: why are American and British IPE so different?' Review of International Political Economy 14(2): 197-219.

2001. 'Electronic money: new day or false dawn?'. Review of International Political Economy 8(2): 197-225.

2006. The future of money. Princeton: Princeton University Press.

Connolly, William E.2013. 'The "new materialism" and the fragility of things'. Millennium 41(3): 399-412.

Coole, Diana and Samantha Frost (eds). 2010. The new materialisms: ontology, agency and politics. Durham: Duke University Press.

De Goede, Marieke. 2006. 'International political economy and the promises of poststructuralism'. In Marieke de Goede (ed), International political economy and poststructural politics. Basingstoke and New York: Palgrave, pp. 1-20. 


\section{Anna Leander}

2012a. 'The SWIFT affair and the global politics of European security'. Journal of Common Market Studies 50 (2): 214-30.

2012b. Speculative security: the politics of pursuing terrorist monies. Minneapolis: University of Minnesota Press.

DeGoede, Marieke, Anna Leander and Gavin Sullivan. 2015. 'The politics of security listing: classification, criteria, consequence, critique'. In review.

DeLanda, Manuel. 2006. A new philosophy of society: assemblage theory and social complexity. London and New York: Continuum.

Flathman, Richard E.1980. The practice of political authority: authority and the authoritative. Chicago: Chicago University Press.

Fuller, Matthew and Andrew Goffey. 2012. 'Digital infrastructures and the machinery of topological abstraction'. Theory, Culture \& Society 29 (4-5): 311-33.

Gutwirth, Serge and Mireille Hildebrandt (eds). 2008. Profiling the European citizen: cross-disciplinary perspectives. Dordrecht: Springer.

Haraway, Donna. 1997.Witness@Second_Millennium.FemaleMan@_Meets_ Onco

Mouse: Feminism and Technoscience. New York: Routledge.

Hayles, KatherineN. 2012. How we think: digital media and contemporary technogenesis. Chicago: Chicago University Press.

Hibou, Béatrice. 2011. Anatomie politique de la domination. Paris: La Découverte.

Kirschner, Jonathan. 2007. Appeasing bankers: financial caution on the road to war. Princeton: Princeton University Press.

1995. Currency and coercion: the political economy of international monetary power. Princeton, NJ: Princeton University Press.

Knorr-Cetina, Karin. 2005. 'How are global markets global? The architecture of a flow world'. In Karin Knorr-Cetina and Alex Preda (eds), The sociology of financial markets. Oxford: Oxford University Press, pp. 17-37.

1997. 'Sociality with objects: social relations in postsocial knowledge societies'. Theory, Culture \& Society 14(4): 1-30. 
Theorising international monetary relations: three questions about the significance...

Knorr-Cetina, Karinand Alex Preda (eds). 2005. The sociology of financial markets. Oxford: Oxford University Press.

Krieger, Leonard. 1977. 'The idea of authority in the West'. American Historical Review 82(2).

Langely, Paul. 2008. The everyday of global finance: saving and borrowing in Anglo-America. Oxford: Oxford University Press.

Larner, Wendy and William P Walters. 2004. 'Introduction: global governmentality'. In Wendy Larner and William P Walters (eds), Global governmentality: governing international spaces. London: Routledge, pp. $1-20$.

Latour, Bruno. 2005. Reassembling the social: an introduction to Actor Network Theory. Oxford: Oxford University Press.

Latour, Bruno and Peter Weibel (eds). 2005. Making things public: atmospheres of democracy. Harvard: MIT Press.

Law, John. 1991. A sociology of monsters: essays on power, technology and domination. London: Routledge.

Leander, Anna, Nina Boy and Peter JBurgess. 2011. 'The global governance of security and finance: introduction to the special issue'. Security Dialogue 42 (1): $1-8$.

MacKenzie, Donald. 2006. An engine, not a camera. How financial models shape markets. Cambridge: MIT Press.

_.2014a. 'Be grateful for a drizzle'. Manuscript.

2014b. 'A sociology of algorithms'. Manuscript.

Mayer-Schönberger, Viktor and Kenneth Cukier. 2013. Big data: a revolution that will transform how we live, work, and think. New York: Eamon Dolan/Houghton Mifflin Harcourt.

McKeen-Edwards, Heather and Tony Porter. 2013. Transnational financial associations and the governance of global finance. London and New York: Routledge.

Nitsche, Christoph and Chris Hope. 1993. Banks as 'policemen': money laundering and the proposed European environmental liability legislation. Cambridge: Judge Institute of Management Studies. 


\section{Anna Leander}

Porter, Tony. 2013. 'Tracing associations'. International Political Sociology 7(3): 334-37.

Power, Michael. 2005. 'The invention of operational risk'. Review of International Political Economy 12(4): 577-99.

Srnicek, Nick; Maria Fotou and Edmund Arghand. 2013. 'Introduction: materialism and world politics'. Millennium 41(3): 397.

Star, Susan Leigh. 2010. 'This is not a boundary object: reflections on the origin of a concept'. Science, Technology, \& Human Values 35 (5): 601-17.

Strange, Susan. 1990. 'The name of the game'. In Nicos Rizopoulos (ed), Sea changes: American foreign policy in a world transformed. New York and London: Council on Foreign Relations Press, pp. 238-74.

1996. The retreat of the state: the diffusion of power in the world economy. Cambridge: Cambridge University Press.

1998. Mad money. Manchester: Manchester University Press.

1999. ‘The West failure system'. Review of International Studies 25 (3): 345-54.

Underhill, Geoffrey. 1995. 'Keeping governments out of politics: transnational securities, markets, regulatory cooperation, and political legitimacy'. Review of International Studies 25: 251-78.

\section{Abstract}

\section{Theorising international monetary relations: three questions about the significance of materiality}

This article engages a conversation with Benjamin Cohen by raising three questions about the significance of materiality. The paper's questions focus on how materiality can be included in theorizations so that its political import is not defined away from the outset. The article does this focussing on Cohen's treatment of electronic money and its significance for the Politics of International Monetary Relations. The first question posed is about ontology, the second about agency and the third about the scope of politics. The three questions are raised as a conversation in which 
Theorising international monetary relations: three questions about the significance...

arguments and counterarguments are advanced. The questions are therefore posed with Cohen's contributions to theorizing the political significance of materiality as their point of departure. They are formulated as a consequence of bringing these contributions in relation to insights from the Social Studies of Finance. From this perspective it would seem that a more far reaching engagement with materiality (in terms of ontology, agency and epistemology) is necessary to capture its political significance for international monetary politics and currency hierarchies. The article does not conclude in conventional fashion but purposefully strives to leave these questions open for discussion.

Keywords: Electronic Money - Digital - New Materialism - Materiality Security - Ontology 